\title{
Statistical Analyses and Modeling of the Implementation of Agile Manufacturing Tactics in Industrial Firms
}

\author{
Mohammad D. AL-Tahat ${ }^{1}$ and Khaled M. Bataineh ${ }^{2}$ \\ ${ }^{1}$ Industrial Engineering Department, The University of Jordan, Amman 11942, Jordan \\ ${ }^{2}$ Department of Mechanical Engineering, Jordan University of Science and Technology, Irbid 22110, Jordan \\ Correspondence should be addressed to Mohammad D. AL-Tahat, altahat@ju.edu.jo
}

Received 5 January 2012; Revised 22 April 2012; Accepted 4 June 2012

Academic Editor: Sri Sridharan

Copyright (c) 2012 M. D. AL-Tahat and K. M. Bataineh. This is an open access article distributed under the Creative Commons Attribution License, which permits unrestricted use, distribution, and reproduction in any medium, provided the original work is properly cited.

This paper provides a review and introduction on agile manufacturing. Tactics of agile manufacturing are mapped into different production areas (eight-construct latent): manufacturing equipment and technology, processes technology and know-how, quality and productivity improvement, production planning and control, shop floor management, product design and development, supplier relationship management, and customer relationship management. The implementation level of agile manufacturing tactics is investigated in each area. A structural equation model is proposed. Hypotheses are formulated. Feedback from 456 firms is collected using five-point-Likert-scale questionnaire. Statistical analysis is carried out using IBM SPSS and AMOS. Multicollinearity, content validity, consistency, construct validity, ANOVA analysis, and relationships between agile components are tested. The results of this study prove that the agile manufacturing tactics have positive effect on the overall agility level. This conclusion can be used by manufacturing firms to manage challenges when trying to be agile.

\section{Introduction}

Agile manufacturing (AM) is described as new tactics of manufacturing. It emerged after lean production (LP). It represents pattern shifts from mass production (MP). It originated from the 21st century manufacturing enterprise study that was conducted at Lehigh University in the early 1990s [1]. Following that, a book entitled "Agile Companies and Virtual Enterprise" recognized as the state-of-the-art work on AM was published in 1995.

According to Groover [1] "agile manufacturing can be defined as: (1) an enterprise level manufacturing strategy of introducing new products into rapidly changing markets, (2) an organizational ability to thrive in a competitive environment characterized by continuous and sometimes unforeseen change". Pham et al. [2] defined agile manufacturing as the ability 
to thrive in a competitive environment of continuous unpredictable change and respond quickly to rapidly changing market driven by customer-based value of products and services.

The international CAM-I [3] addressed the capabilities of an enterprise to reconfigure itself quickly in response to sudden changes, but in ways that are cost effective, timely, robust, and of a broad scope. Agility theory seeks to provide matrices for business processes, physical operations, and human resources to respond to rapid and unpredictable changes.

Agile companies tend to reveal the following agile principles: (1) rapid configuration of resources to meet dynamic change of market opportunities; (2) managerial personnel needs and knowledge should be distributed to all level of enterprise on trust base; (3) building business relationships to effectively enhance competitiveness; (4) considerable attention on innovation and entrepreneurship should be highly considered; (5) considerable attention on the value of solutions to customers' problems rather than on the product cost and price.

Important aspects and tactics of $\mathrm{AM}$ are mapped into different production areas as shown in Table 1. The main focus of this study is to investigate and measure an agility index that represents the overall implementation of AM tactics in Jordanian industrial firms. After a Structural Equation Model (SME) is proposed, related hypotheses are formulated. Necessary statistical analysis is carried out using the proper tools. Finally, results are presented and discussed.

\section{Comparison of Agile Manufacturing and Lean Production}

LP and AM are complement to each other and should not be viewed as competitive. They are mutually supportive. On the other hand, LP and AM use different statements of principles. The emphasis in LP seems to be more on technical and operational issues, while emphasis in $\mathrm{AM}$ is on enterprise and people issues. AM is broader in scope and more applicable to the enterprise level. On the other hand, LP tries to smooth out the production schedule and reduce batch sizes $[1,4]$.

AM uses flexible production technology to minimize disruptions due to design changes. By contrast, the philosophy behind AM is to embrace unpredictable changes. The capacity of an agile company to adapt to changes depends on its capabilities to minimize the time and the cost of setup and changeover, to reduce inventories of finished products, and to avoid other forms of waste. Table 2 summarizes some differences between LP and AM in many different business dimensions [1,2]. The products are customized in both AM and LP. $\mathrm{AM}$ and LP want to have continuous relationships with their customers. Agile principles focus on the enhancement of enterprise's ability to respond quickly to rapidly changing market driven by customer-based value of products and services. On the other hand, lean principles focus on the elimination of sources of different types of waste. Agile enterprise can be described as lean, while the reverse is not necessary true.

\section{Constructed Latent of Agile Manufacturing System}

The proposed agile manufacturing system (AMS) is assumed to involve eight-construct latent listed in Table 3. These are as follows: (1) manufacturing equipment and technology MET, (2) processes technology and know-how PTK, (3) quality and productivity improvement and measures QPIM, (4) production planning and control PPC, (5) shop floor management SFM, (6) product design and development PDD, (7) supplier relationship management SRM, and

(8) customer relationship management CRM. 
Table 1: Mappings of AM tactics to eight impact areas.

\begin{tabular}{|c|c|c|c|}
\hline Impact area & Identifier & Agile tactic & Identifier \\
\hline \multirow{6}{*}{$\begin{array}{l}\text { (1) Manufacturing } \\
\text { equipment and technology }\end{array}$} & \multirow{6}{*}{ MET } & $\begin{array}{l}\text { Group technology, cellular layouts, continuous } \\
\text { flow }\end{array}$ & GTC \\
\hline & & Production process reengineering & PPR \\
\hline & & Flexible manufacturing system & FMS \\
\hline & & $\mathrm{CNC}$ and $\mathrm{DNC}$ & $\mathrm{CNC}$ \\
\hline & & Robotics and PLC's & PLC \\
\hline & & CAD/CAM, CAPP, and CIM & CIM \\
\hline \multirow{5}{*}{$\begin{array}{l}\text { (2) Processes technology } \\
\text { and know-how }\end{array}$} & \multirow{5}{*}{ PTK } & Removal of waste methods & RWM \\
\hline & & $\begin{array}{l}\text { Reconfigurable, and continuously changeable } \\
\text { system }\end{array}$ & RCS \\
\hline & & Rapid machine setups and changeovers & RSC \\
\hline & & Standardized operating procedures & SOP \\
\hline & & $\begin{array}{l}\text { Rapid prototyping, remote, and } \\
\text { e-manufacturing }\end{array}$ & E-M \\
\hline \multirow{4}{*}{$\begin{array}{l}\text { (3) Quality and productivity } \\
\text { improvement and measures }\end{array}$} & \multirow{4}{*}{ QPIM } & Fast identification of in-process defects & FID \\
\hline & & $\begin{array}{l}\text { Strategic focus on long-term productivity } \\
\text { performance }\end{array}$ & LPP \\
\hline & & Modular production facilities & MPF \\
\hline & & Fast production cycle times & FPT \\
\hline \multirow{4}{*}{$\begin{array}{l}\text { (4) Production planning } \\
\text { and control }\end{array}$} & \multirow{4}{*}{ PPC } & Effective information system & EIS \\
\hline & & Make-to-order strategy & MTO \\
\hline & & Decision making at functional knowledge levels & DMK \\
\hline & & Manufacturing resource planning & MRP \\
\hline \multirow{5}{*}{ (5) Shop floor management } & \multirow{5}{*}{ SFM } & High flexibility approaches & HFS \\
\hline & & General purpose equipments & GPE \\
\hline & & Effective communication technology & ECT \\
\hline & & Removal of waste methods & RWM \\
\hline & & Make-to-lot size & MLT \\
\hline \multirow{4}{*}{$\begin{array}{l}\text { (6) Product design and } \\
\text { development }\end{array}$} & \multirow{4}{*}{ PDD } & Quick introduction of new products & QIN \\
\hline & & Rapid changes to control software & $\mathrm{RCC}$ \\
\hline & & $\begin{array}{l}\text { Rapid prototyping, remote, and } \\
\text { e-manufacturing }\end{array}$ & E-M \\
\hline & & CAD/CAM, CAPP, and CIM & CIM \\
\hline \multirow{3}{*}{$\begin{array}{l}\text { (7) Supplier relationship } \\
\text { management }\end{array}$} & \multirow{3}{*}{ SRM } & Effective communication technology & ECT \\
\hline & & Long-term supplier relationship & LTR \\
\hline & & Supplier evaluation and selection & SES \\
\hline \multirow{5}{*}{$\begin{array}{l}\text { (8) Customer relationship } \\
\text { management }\end{array}$} & \multirow{5}{*}{ CRM } & Immediate and quick delivery & IQD \\
\hline & & Effective communication technology & ECT \\
\hline & & Make-to-order strategy & MTO \\
\hline & & Competitive unit cost & CUC \\
\hline & & Product customization & PCU \\
\hline
\end{tabular}


Table 2: Comparison of agile manufacturing and lean production.

\begin{tabular}{|c|c|c|}
\hline Dimension & Lean production & Agile manufacturing \\
\hline Principles & $\begin{array}{l}\text { Eliminate source of waste } \\
\text { Perfect first-time quality } \\
\text { Flexible production lines } \\
\text { Kaizen }\end{array}$ & $\begin{array}{l}\text { Customer enrichment } \\
\text { Cooperate to enhance competitiveness } \\
\text { Organize to master change } \\
\text { Leverage the impact of people and } \\
\text { information }\end{array}$ \\
\hline Production quantity & Enhancement of mass production & $\begin{array}{l}\text { Break with mass production; emphasis } \\
\text { on mass customization }\end{array}$ \\
\hline Production flexibility & $\begin{array}{l}\text { Flexible production for product } \\
\text { variety }\end{array}$ & $\begin{array}{l}\text { Greater flexibility for customized } \\
\text { products }\end{array}$ \\
\hline Emphasis & $\begin{array}{l}\text { On technical, operational issues and } \\
\text { management of human resources }\end{array}$ & On organizational and people issues \\
\hline Application 1 & To the factory level & To the enterprise level \\
\hline Area of management & Emphasis on supplier management & Formation of virtual enterprises \\
\hline \multirow[t]{2}{*}{ Area of change } & $\begin{array}{l}\text { Relies on smooth production } \\
\text { schedule }\end{array}$ & Attempts to be responsive to change \\
\hline & $\begin{array}{l}\text { Attempts to eliminate source of } \\
\text { waste }\end{array}$ & Embrace unpredictable market change \\
\hline Market life & Short & Short \\
\hline Order initiation & Produce to order & Produce to order \\
\hline Information content & High & High \\
\hline \multirow{2}{*}{ Customer relationship } & Continuing relationship & Continuing relationship \\
\hline & Pricing by customer value & Pricing by customer value \\
\hline
\end{tabular}

Table 3: Constructed latent of agile manufacturing system.

\begin{tabular}{lclc}
\hline & No. & Constructed latent & Identifier \\
\hline & 1 & Manufacturing equipment and technology & MET \\
& 2 & Processes technology and know-how & PTK \\
& 3 & Quality and productivity improvement and measures & QPIM \\
Agile manufacturing & 4 & Production planning and control & PPC \\
system (AMS) & 5 & Shop floor management & SFM \\
& 6 & Product design and development & PDD \\
& 7 & Supplier relationship management & SRM \\
& 8 & Customer relationship management & CRM \\
\hline
\end{tabular}

\subsection{Agile Selection of Manufacturing Equipment and Technology (MET)}

The relations between the specific equipment configurations with visual control and group technology are developed by $[5,6]$. The explanations of how to design cellular layouts are given by [7, 8]. Li-Hua and Khalil [9] investigated the rapid changes in the business environment. They showed how companies can maximize business opportunities when the risks are considered. The relation between new equipment/technologies and production process reengineering is developed by $[10,11]$. A discussion about how the production 
process reengineering increases productivity and efficiency is presented in $[12,13]$. In order to have a formal investigation about the effect of MET, the following hypotheses are proposed:

$H 1_{0}$ : MET implementation has a significant, positive effect on the development of AMS.

$H 1_{1}$ : MET implementation has no effect on the development of AMS.

$\mathrm{H} 2_{0}$ : MET implementation has a significant, positive effect on the development of PTK.

$H 2_{1}$ : MET implementation has no effect on the development of PTK.

$H 3_{0}$ : MET implementation has a significant, positive effect on the development of QPIM.

$H 3_{1}$ : MET implementation has no effect on the development of QPIM.

$\mathrm{H}_{0}$ : MET implementation has a significant, positive effect on the development of SFM.

$H 4_{1}$ : MET implementation has no effect on the development of SFM.

$H 5_{0}$ : MET implementation has a significant, positive effect on the development of PDD.

$H 5_{1}$ : MET implementation has no effect on the development of PDD.

\subsection{Processes Technology and Know-How (PTK)}

The elimination of waste can (1) simplify organizations processes [14], (2) allow business to be more agile and dynamic which offers the opportunity to meet customer demands in new products and services, and (3) allow business to be more responsive to customers' concerns [15].

Researchers on AM have established that flexibility is the foundation of AM. Flexibility is classified into machine flexibility, routing flexibility, product flexibility, manufacturing system flexibility, strategic flexibility, volume flexibility, and so forth, [16]. Yusuf et al. [14] stated that "agility is reflected in: the successful exploration of competitive bases through the integration of reconfigurable resources and best practices in a knowledge-rich environment to provide customer-driven products and services in a fast-changing market environment".

Quinn et al. [17] defined agility as the ability to accomplish rapid changeover from the assembly of one product to the assembly of different product [18]. Gunasekaran [19] found that the rapidprototyping is one of the major enablers of agility. Prototyping describes the design and generation of an early version of product. Many strategies/techniques such as rapid-partnership formation, e-manufacturing, and rapid prototyping can be employed to improve the responsiveness of the overall system for customer requirements [19]. This eventually leads to an increase in the customers' investments. Accordingly, the following hypotheses are formulated:

H6 $6_{0}$ : PTK implementation has a significant, positive effect on the development of AMS.

$H 6_{1}$ : PTK implementation has no effect on the development of AMS.

$H 7_{0}$ : PTK implementation has a significant, positive effect on the development of QPIM.

$H 7_{1}$ : PTK implementation has no effect on the development of QPIM.

\subsection{Quality and Productivity Improvement and Measures (QPIM)}

Hormozi [20] stated that agile manufacturing produces defect free product. Misra et al. [21] stated that agile approaches result in lower defect rates through fast identification 
of in-process defects. Agility achieves improvements in productivity and quality through flexibility of access and utilization of resources [22]. Gunasekaran [19] showed that manufacturing performance measures such as productivity would help to design the most effective agile manufacturing system.

Agile-based manufacturing organizations have higher productivity market shares [23]. Several researchers use productivity and quality as measures for process performance [24]. Others use different measures such as the multidimensional index created by Schroeder et al. [25]. AM requires modular production facilities. Gunasekaran [26] found out that AM characterized the needs for modular production facilities in decision making.

AM involves fundamental change in an organization's approach to cycle-time reduction [27]. Naylor et al. [28] showed the necessity for production lead time reduction as a prerequisite to agility. Short production lead times were addressed in [23]. Sieger et al. [29] measured responsiveness of companies relative to the product development cycle time. Vinodh and Kuttalingam [30] suggested that the one major constituent of AM is the minimization of manufacturing lead times. Accordingly, the following hypotheses are proposed:

$\mathrm{H}_{8}$ : QPIM implementation has a significant, positive effect on the development of AMS. $H 8_{1}$ : QPIM implementation has no effect on the development of AMS.

$H 9_{0}$ : QPIM implementation has a significant, positive effect on the development of SRM.

$H 9_{1}$ : QPIM implementation has no effect on the development of SRM.

$H 10_{0}$ : QPIM implementation has a significant, positive effect on the development of CRM.

$H 10_{1}$ : QPIM implementation has no effect on the development of CRM.

\subsection{Production Planning and Control (PPC)}

Production planning and control PPC plays an important role in the competitive environments. PPC responds immediately to achieve higher service level of performance, better resource utilization, and less material loss. Yan [31] established an approach to stochastic production planning SPP for flexible automation in agile manufacturing environment. Li et al. [32] concluded that the performance of customer service level in enterprises is highly dependent on the effectiveness of its manufacturing planning and control system. Chen [33] discussed four problems of production management in the environment of agile manufacturing. These problems are (1) organization of production, (2) production planning, (3) production control, and (4) quality control. Le et al. [34] described the production planning methodology that can be implemented in agile manufacturing. They studied two multiitem lot-sizing problems. They detailed the development of the planning problem mathematically and highlighted solutions to some of their initial problems. Tunglun and sato [35] provided a model of PPC that concretely defines the PPC and allows the possibility for immediate planning and scheduling.

Gold and Thomas [36] discussed and simulated lean, agile, and hybrid supply chain strategies. Their study demonstrated that while lean management typically calls for maketo-stock replenishment driven by short-term forecasts, agile supply chains employ make-toorder provisions. Ching et al. [37] provided a structured procedure for identifying the agile drivers in the business environment. They determined the management information system requirements that enhance manufacturing agility. Adrian et al. [38] studied the evolution of 
information systems in manufacturing and its importance in supporting agile manufacturing. Lenny and Mike [39] concluded that the application of enterprise resource planning (ERP) has improved agility and responsiveness.

Petri [40] showed that resource management is an important part of any production system, especially when building agility in the manufacturing of the company. David and Chong [41] presented a review of agile supply partner decision making published between 2001 and 2011. The progress made in developing new models and methods applicable to this task is assessed in the context of the previous literature. Particular attention is given to those methods that are especially relevant for the use of agile in supply chains. The review highlighted the ongoing need for developing methods that are able to meet the combination of qualitative and quantitative objectives. These objectives are typically found in partner selection. Based on previous discussion, we theorized the following hypotheses:

$H 11_{0}$ : PPC implementation has a significant, positive effect on the development of AMS.

H11 1 : PPC implementation has no effect on the development of AMS.

H12 $2_{0}$ PPC implementation has a significant, positive effect on the development of SFM.

$H 12_{1}$ : PPC implementation has no effect on the development of SFM.

\subsection{Shop Floor Management (SFM)}

In 1995, shop floor control functional diagram was developed by Technologies Enabling Agile Manufacturing "TEAM" [42]. A hybrid integration approach was developed to solve the problem of shop floor scheduling [43]. Ribeiro et al. demonstrated how the seamless integration of the shop floor with external tools is achieved [44]. A multiagent architecture of agile manufacturing system and a hybrid strategy for shop floor scheduling were adopted by Li et al. [45]. Software architecture for control of an agile manufacturing work cell is developed by Kim et al. [46]. Jacobs et al. provided a strong empirical evidence of the advantages of increasing the modularity of products in the firm's portfolio [47]. Chick et al. provided a descriptive model of the machining system selection process that is focused on capital intensive [48]. Swafford et al. found that information technology integration enables firms to utilize their flexibility [49]. Jacobs et al. studied the product and process modularity's effects on manufacturing agility and firm growth performance [47]. Forsythe summarized human factors contributions to the development of agile business practices and design of enabling technologies. The author also discussed human factors related to the communications and information infrastructure essential to organization to become agile [50]. Chunxia and Shensheng proposed a web-based agile architecture of supply chain management system [51]. Moore et al. proposed virtual manufacturing approach for designing, programming, testing, verifying, and deploying control systems for agile modular manufacturing machinery [52]. Based on previous discussion, we suggest the following hypothesis:

$H 13_{0}$ : SFM implementation has a significant, positive effect on the development of AMS.

$H 13_{1}$ : SFM implementation has no effect on the development of AMS. 


\subsection{Product Design and Development (PDD)}

Andrew [53] considered the outsourcing strategy and how it affects product design. He explained how outsourcing permits manufacturers to remain more agile and competitive by retaining local manufacture. Computer-aided design (CAD) is used to bring out new models for achieving design agility [54]. Agility is greatly influenced by the emergence and growth of new technologies such as CAD, CAM, CNC, RP, and so forth, [55]. Modular architecture for developing product platform is crucial to agile manufacturing and product variety that satisfies various customers' needs and high agility [56]. The relations of CAPP/CAM packages, simulators, design analysis and synthesis tools, and decision support systems with agility are discussed in [57]. Based on this analysis, we postulate the following hypothesis:

$H 14_{0}$ : PPD implementation has a significant, positive effect on the development of AMS.

$H 14_{1}$ : PPD implementation has no effect on the development of AMS.

\subsection{Supplier Relationship Management (SRM)}

SRM practices create common frame of reference to enable effective communication between enterprises. In agile environments, relationships and communication between suppliers should be flexible and responsive [58]. Relationships with suppliers in agile manufacturing are considered in $[26,59]$. Accordingly, we theorize the following hypothesis:

$H 15_{0}$ : SRM implementation has a significant, positive effect on the development of AMS. $H 15_{1}$ : SRM implementation has no effect on the development of AMS.

\subsection{Customer Relationship Management (CRM)}

Traditional ways of communication with customers include Internet, business to customer B2C, business to business B2B. The Internet offers several advantages such as reduction of ordering process cost, revenue flow increase because of credit cards payment, global access, and pricing flexibility. In-house inventory placement, inventory pooling, forward placement, vendor-managed inventories VMI, and continuous replenishment program CRP may be used to build an effective agile customer relationship model. Hence, the following hypothesis is proposed:

H16 0 : CRM implementation has a significant, positive effect on the development of AMS. $H 16_{1}$ : CRM implementation has no effect on the development of AMS.

\section{Structural Equation Model (SME) and Research Hypotheses}

The conceptual relationship model between the eight-construct latent considered in this study is shown in Figure 1. The relationships between the various-model latent are defined and summarized in Table 4. The relationship model is constructed based on authors' experience. Therefore, this model investigates the important relationships between the eight considered agile areas and the impacts of their implementations on the development of AMS.

Eight different questionnaire drafts were developed. The preliminary questionnaires were pilot tested and reviewed by managers of several industrial companies, extensive 


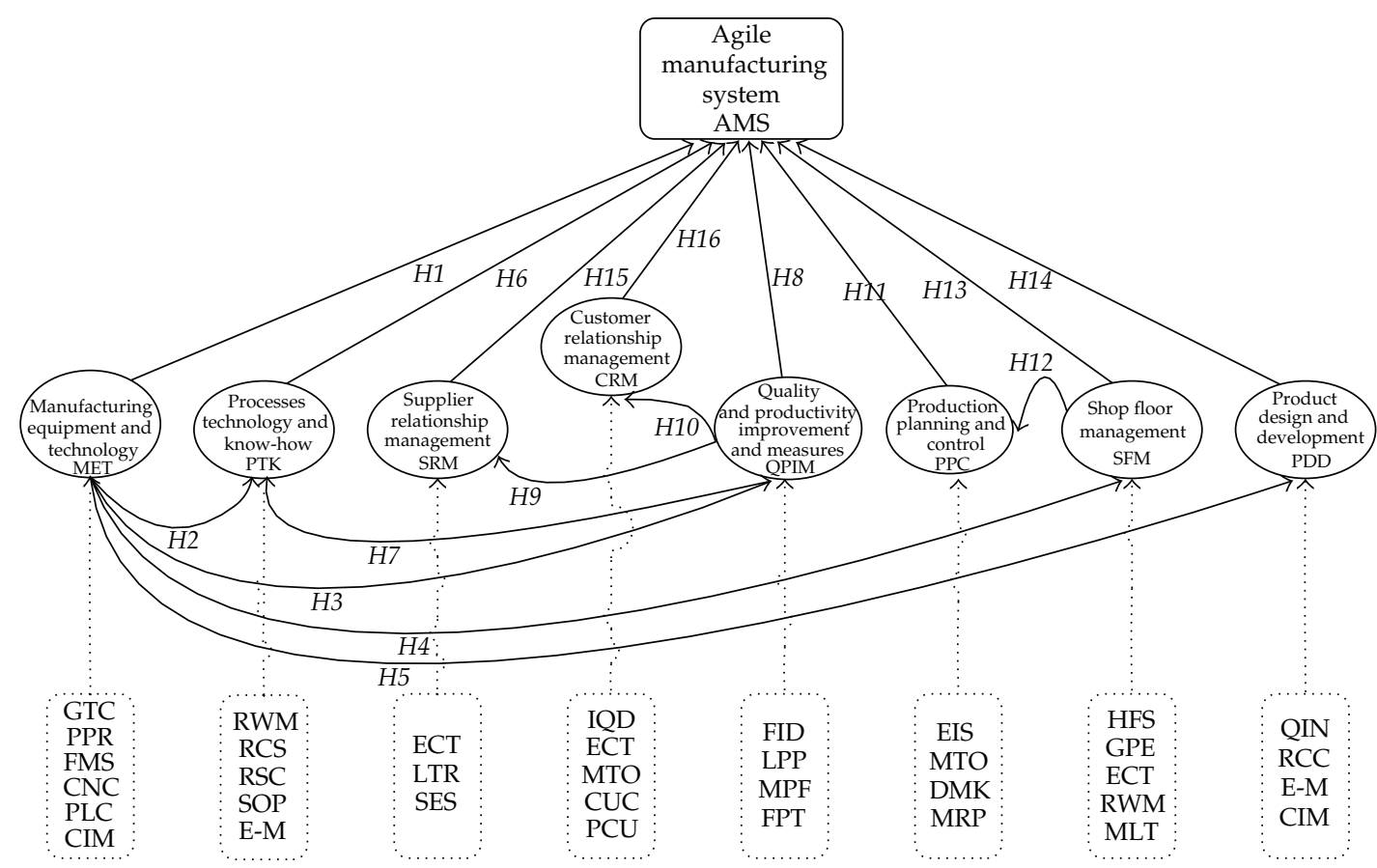

Figure 1: The proposed conceptual model and research hypotheses.

literature review, and group of graduate students. This process continues until all questions in the eight questionnaires are unambiguous, appropriate, and acceptable to respondents. Every questionnaire is concerned with the implementation of one impact area. It consists of five-point Likert scale anchored at (1) "Poor", (2) "Fair", (3) "Good", (4) "Very good", and (5) "Excellent".

\section{Data Collection and Analysis}

Jordanian companies listed in Jordan chamber of commerce were screened according to whether they have a potential of implementing lean tools or not. Consequently, questionnaire packets were distributed to 500 services and manufacturing companies. 456 companies have responded to the questionnaire packets. Data were collected through production managers, quality engineers, consultants, and owners. Cronbach's alpha $\alpha$ is a tool that measures and tests consistency validity and scale reliability. As shown in Table 5, Cronbach's alpha value of the whole AMS equals to 0.830 and the AGility index is $60.1 \%$. AG is used to measure the overall implementation level of agile tactics in the studied sample. The results of reliability test indicate that both internal consistency and overall model reliability are high. Mean $\mu$, variance $\sigma^{2}$, area-tactic correlations, model-tactic correlations, tactic agility indexarea correlations, and area agility index are evaluated and summarized in Table 6. Agile tactics with no significant correlations at the 0.05 or less level ( 2 tailed) are identified. The results of tactics-tactics correlation test are summarized in Table 7.

Interrelations between production areas are computed and investigated using correlation coefficients (see Table 8). It is observed that the correlation is significant at the 
Table 4: Summary of relationships between various-model latent.

\begin{tabular}{|c|c|c|}
\hline$H 16$ & $\begin{array}{l}H 16_{0} \\
H 16_{1}\end{array}$ & $\begin{array}{l}\text { CRM implementation has a significant, positive effect on the development of AMS. } \\
\text { CRM implementation has no effect on the development of AMS. }\end{array}$ \\
\hline \multirow{2}{*}{ H15 } & $H 15_{0}$ & SRM implementation has a significant, positive effect on the development of AMS. \\
\hline & $H 15_{1}$ & SRM implementation has no effect on the development of AMS. \\
\hline \multirow{2}{*}{$H 14$} & $H 14_{0}$ & PPD implementation has a significant, positive effect on the development of AMS. \\
\hline & $H 14_{1}$ & PPD implementation has no effect on the development of AMS. \\
\hline \multirow{2}{*}{$H 13$} & $H 13_{0}$ & SFM implementation has a significant, positive effect on the development of AMS. \\
\hline & $H 13_{1}$ & SFM implementation has no effect on the development of AMS. \\
\hline \multirow{2}{*}{$H 12$} & $H 12_{0}$ & PPC implementation has a significant, positive effect on the development of SFM. \\
\hline & $H 12_{1}$ & PPC implementation has no effect on the development of SFM. \\
\hline \multirow{2}{*}{$H 11$} & $H 11_{0}$ & PPC implementation has a significant, positive effect on the development of AMS. \\
\hline & $H 11_{1}$ & PPC implementation has no effect on the development of AMS. \\
\hline \multirow{2}{*}{$H 10$} & $H 10_{0}$ & QPIM implementation has a significant, positive effect on the development of CRM. \\
\hline & $H 10_{1}$ & QPIM implementation has no effect on the development of CRM. \\
\hline \multirow{2}{*}{ H9 } & $H 9_{0}$ & QPIM implementation has a significant, positive effect on the development of SRM. \\
\hline & $H 9_{1}$ & QPIM implementation has no effect on the development of SRM. \\
\hline \multirow{2}{*}{ H8 } & $H 8_{0}$ & QPIM implementation has a significant, positive effect on the development of AMS. \\
\hline & $H 8_{1}$ & QPIM implementation has no effect on the development of AMS. \\
\hline \multirow{2}{*}{$H 7$} & $H 7_{0}$ & PTK implementation has a significant, positive effect on the development of QPIM. \\
\hline & $H 7_{1}$ & PTK implementation has no effect on the development of QPIM. \\
\hline \multirow{2}{*}{ H6 } & $H 6_{0}$ & PTK implementation has a significant, positive effect on the development of AMS. \\
\hline & $H 6_{1}$ & PTK implementation has no effect on the development of AMS. \\
\hline \multirow{2}{*}{ H5 } & $H 5_{0}$ & MET implementation has a significant, positive effect on the development of PDD. \\
\hline & $H 5_{1}$ & MET implementation has no effect on the development of PDD. \\
\hline \multirow{2}{*}{ H4 } & $H 4_{0}$ & MET implementation has a significant, positive effect on the development of SFM. \\
\hline & $H 4_{1}$ & MET implementation has no effect on the development of SFM. \\
\hline \multirow{2}{*}{ H3 } & $H 3_{0}$ & MET implementation has a significant, positive effect on the development of QPIM. \\
\hline & $H 3_{1}$ & MET implementation has no effect on the development of QPIM. \\
\hline \multirow{2}{*}{$H 2$} & $H 2_{0}$ & MET implementation has a significant, positive effect on the development of PTK. \\
\hline & $H 2_{1}$ & MET implementation has no effect on the development of PTK. \\
\hline \multirow{2}{*}{$H 1$} & $H 1_{0}$ & MET implementation has a significant, positive effect on the development of AMS. \\
\hline & $H 1_{1}$ & MET implementation has no effect on the development of AMS. \\
\hline
\end{tabular}

Table 5: Consistency and reliability of the model.

\begin{tabular}{cccccc}
\hline & $\begin{array}{c}\text { Model mean } \\
(\mu)\end{array}$ & $\begin{array}{c}\text { Model variance } \\
\left(\sigma^{2}\right)\end{array}$ & $\begin{array}{c}\text { Cronbach's } \\
\text { alpha }\end{array}$ & $\begin{array}{c}\text { Internal } \\
\text { correlations }\end{array}$ & $\begin{array}{c}\text { Agility index } \\
(\mathrm{AG} \%)\end{array}$ \\
\hline Model & 3.003 & 0.008 & 0.830 & 0.011 & 60.1 \\
\hline
\end{tabular}

0.01 level (2 tailed) between some areas like MET-CRM, CRM-SRM. On the other hand, SRMPDD correlation and CRM-SRM correlation is significant at the 0.05 level (2 tailed), where there is no significant correlation between SRM and PPC. AMOS software version 19 is used to test the model fit for each area. The results of the area-area correlation test and fit indices are shown in Table 8. A good model fit is found. All items loading on their corresponding production area are high and significant at the 0.05 or less level (2 tailed). Significance level at 0.05 is recommended. 
Mathematical Problems in Engineering

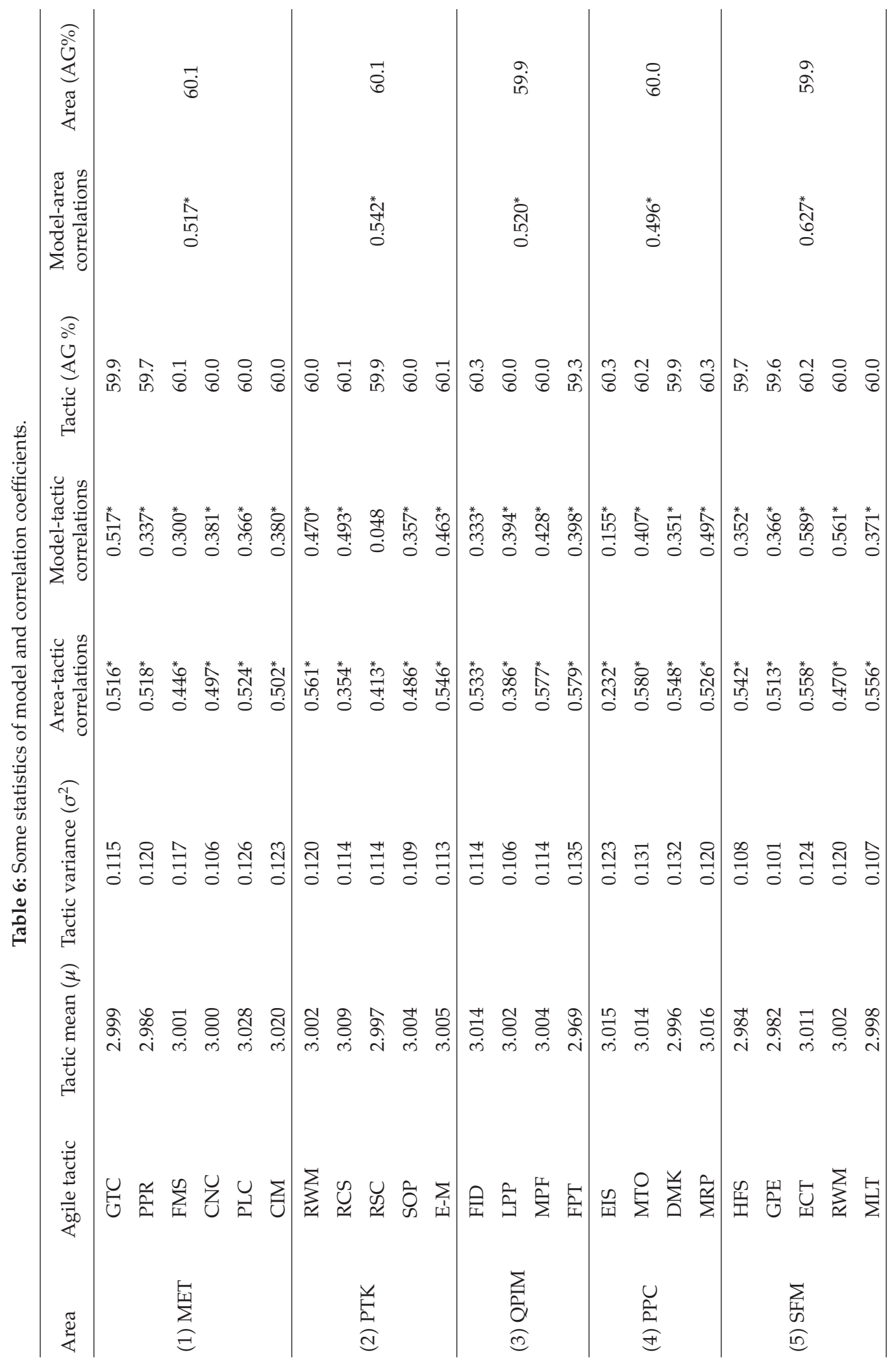




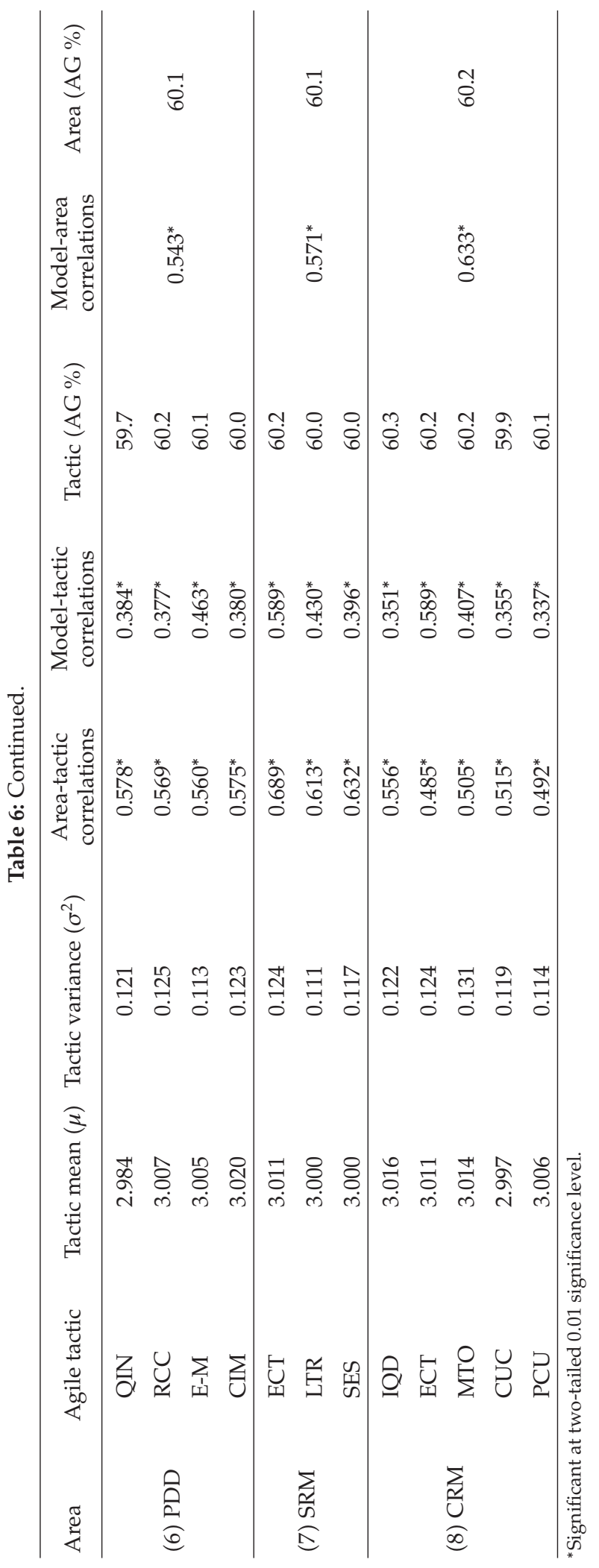


Table 7: Tactic-tactic correlations at two-tailed significance level less than or equal to 0.05 .

\begin{tabular}{|c|c|c|c|c|c|c|c|c|c|c|c|c|c|c|}
\hline \multirow{2}{*}{$\begin{array}{l}\text { Independent } \\
\text { tactic }\end{array}$} & \multicolumn{14}{|c|}{ Dependent tactic } \\
\hline & MLT & MTO & EIS & MBF & FID & RSC & RCS & RWM & CIM & PLC & $\mathrm{CNC}$ & FMS & PPR & GTC \\
\hline$\overline{\mathrm{PPR}}$ & & & & & & & & & & & & & No & \\
\hline $\mathrm{CNC}$ & & & & & & & & & & & & No & & \\
\hline PLC & & & & & & & & & & & & & No & \\
\hline CIM & & & & & & & & & & & & No & & \\
\hline RSC & & & & & & & No & No & No & No & No & No & No & No \\
\hline SOP & & & & & & No & & & & & & & No & \\
\hline EM & & & & & & No & & & & & & & & \\
\hline FID & & & & & & No & & & & & & & & \\
\hline LPP & & & & & & No & & No & & & & & & \\
\hline $\mathrm{MBF}$ & & & & & & No & & & & & & & & \\
\hline FPT & & & & & No & No & No & & & & & & & No \\
\hline EIS & & & & No & & No & & & & No & & & & \\
\hline МTO & & & & & & No & & & & No & No & No & & \\
\hline DMK & & & & & & No & & & & & & & & \\
\hline MRP & & & & & & No & No & & & & & & & \\
\hline HFS & & & & & & No & & & & & & & & \\
\hline GPE & & & & & & No & & & & & & & & No \\
\hline ECT & & No & & & No & No & & & & & & & & \\
\hline MLT & & & No & & & No & & & & & & & & \\
\hline QIN & & & & & & No & & & & No & & & & No \\
\hline RCC & No & & & & No & No & & & & & & & & \\
\hline LTR & & & & & & No & & & & & & & & \\
\hline SES & & & & & No & No & & & No & & & & & \\
\hline IQD & No & & & & & No & & & & & No & & & \\
\hline CUC & & & No & No & & No & & & & & & & & \\
\hline PCU & & & & & & No & & & & & & & & No \\
\hline
\end{tabular}

No: Signifies no tactic-tactic correlation; otherwise there is a tactic-tactic correlation.

Table 9 summarizes the results of the hypothesis testing. The $P$ values of the alterative hypotheses $\left(H 1_{1}, H 2_{1}, H 3_{1}, H 4_{1}, H 5_{1}, H 6_{1}, H 7_{1}, H 8_{1}, H 9_{1}, H 10_{1}, H 11_{1}, H 12_{1}, H 13_{1}\right.$, $H 14_{1}, H 15_{1}$, and $H 16_{1}$ ) are calculated. The calculated $P$-values are less than 0.05 , which indicates that the proposed null hypotheses are true. The $t$-values fall within the $95 \%$ of the $t$-distribution $\left(-1.96=-t_{0.025,458}<t\right.$-Value $\left.<t_{0.025,458}=1.96\right)$. These results provide evidence that the alternative hypotheses are rejected. Influential dependencies (see Table 10) between production areas are found, and hence multicollinearity is achieved. For the twotailed one-way ANOVA test at the 0.05 level, the $f_{0}$-value as shown in Table 10 exceeds $\left(f_{0.025, v 1, v 2}\right)$. This proves that all the considered agile tactics have a positive effect on AMS. The $f_{0}$-value of the $F$-test obtained from the two-tailed one-way ANOVA analysis is less than 0.001 . 


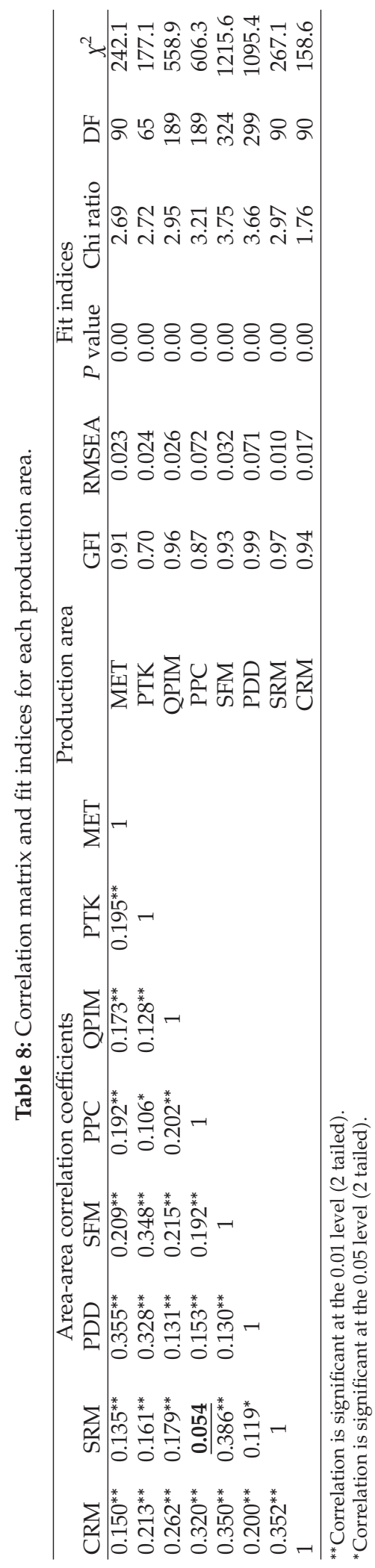


Table 9: Hypothesis testing results.

\begin{tabular}{lccccccc}
\hline \multirow{2}{*}{ Alternative hypothesis } & \multicolumn{2}{c}{ Internal correlation } & \multicolumn{2}{c}{ Paired samples test } & \multirow{2}{*}{$P$ value } & \multirow{2}{*}{ Decision } \\
& Area-area & Pearson & $t$-value & DF & $P$ value & & \\
\hline$H 16_{1}$ & CRM-AMS & 0.633 & 1.061 & 458 & 0.289 & 0.000 & Reject $H 16_{1}$ \\
$H 15_{1}$ & SRM-AMS & 0.571 & 0.382 & 458 & 0.702 & 0.000 & Reject $H 15_{1}$ \\
$H 14_{1}$ & PPD-AMS & 0.543 & 0.216 & 458 & 0.829 & 0.000 & Reject $H 1_{1}$ \\
$H 13_{1}$ & SFM-AMS & 0.627 & -1.413 & 458 & 0.158 & 0.000 & Reject $H 3_{1}$ \\
$H 12_{1}$ & PPC-SFM & 0.192 & 0.795 & 458 & 0.427 & 0.000 & Reject $H 12_{1}$ \\
$H 11_{1}$ & PPC-AMS & 0.496 & -0.034 & 458 & 0.973 & 0.000 & Reject $H 11_{1}$ \\
$H 10_{1}$ & QPIM-CRM & 0.262 & -1.296 & 458 & 0.196 & 0.000 & Reject $H 1_{1}$ \\
$H 9_{1}$ & QPIM-SRM & 0.179 & -0.809 & 458 & 0.419 & 0.000 & Reject $H 9_{1}$ \\
$H 8_{1}$ & QPIM-AMS & 0.520 & -0.892 & 458 & 0.373 & 0.000 & Reject $H 8_{1}$ \\
$H 7_{1}$ & PTK-QPIM & 0.128 & 0.661 & 458 & 0.509 & 0.006 & Reject $H 7_{1}$ \\
$H 6_{1}$ & PTK-AMS & 0.542 & 0.093 & 458 & 0.926 & 0.000 & Reject $H 6_{1}$ \\
$H 5_{1}$ & MET-PDD & 0.355 & 0.226 & 458 & 0.821 & 0.000 & Reject $H 5_{1}$ \\
$H 4_{1}$ & MET-SFM & 0.209 & 1.297 & 458 & 0.195 & 0.000 & Reject $H 4_{1}$ \\
$H 3_{1}$ & MET-QPIM & 0.173 & 1.001 & 458 & 0.317 & 0.000 & Reject $H 3_{1}$ \\
$H 2_{1}$ & MET-PTK & 0.195 & 0.322 & 458 & 0.748 & 0.000 & Reject $H 2_{1}$ \\
$H 1_{1}$ & MET-AMS & 0.517 & 0.590 & 458 & 0.556 & 0.000 & Reject $H 1_{1}$ \\
\hline
\end{tabular}

\section{Discussion of Results}

This paper investigates the causal relationship model among implementation of thirty-six different agile tactics. These tactics are categorized into eight impact areas (manufacturing equipment and technology MET, processes technology and know-how PTK, quality and productivity improvement and measures QPIM, production planning and control PPC, Shop Floor Management SFM, product design and development PDD, supplier relationship management SRM, and customer relationship management CRM). Analysis of data is carried out using AMOS 19 and IBM SPSS 20 for Windows. The obtained results show strongly that the model is valid. The AMOS 19 software is used to test the model fit for each impact area. The results show that the model fit is good. All items loaded significantly on their corresponding constructs at the 0.05 level. This demonstrates a good model fit. The fit statistics indicate that the hypothesized structural model achieves an acceptable fit such that no further interpretation is required. The testing of the entire hypotheses shows that all impact areas have positive effect on AMS.

It was found out that the overall assumed agility index is about $60 \%$, the average agility index of impact areas is about $60 \%$, and the average agility index of agile tactics is about $60 \%$. The correlation analyses show that all model constructs have a positive correlation with overall AMS model.

Estimates of the relations in the AMS are investigated and summarized as shown in Figure 2. The results of this research may be influenced by the person who fills the questionnaires. This may lead to errors due to the personal reliability and trustworthiness.

\section{Conclusion}

The implementation of agile manufacturing principles and tools in Jordanian firms is investigated. Different agile practices that are adopted by the considered firms to manage 
Table 10: One-way ANOVA analysis.

\begin{tabular}{|c|c|c|c|c|c|c|c|c|c|c|}
\hline Area & Factor & \multicolumn{2}{|c|}{ Sum of squares } & DF & $v_{1}$ & $v_{2}$ & $\begin{array}{l}\text { Mean } \\
\text { square }\end{array}$ & $f_{0}$ & $P$ value & Conclusion \\
\hline \multirow{18}{*}{ MET } & \multirow{3}{*}{ GTC } & Between groups & 27.295 & 155 & \multirow{3}{*}{155} & \multirow{3}{*}{303} & 0.176 & \multirow{3}{*}{2.096} & \multirow{3}{*}{0.000} & \multirow{3}{*}{$\begin{array}{l}\text { GTC has an } \\
\text { effect on MET }\end{array}$} \\
\hline & & Within groups & 25.452 & 303 & & & \multirow{2}{*}{0.084} & & & \\
\hline & & Total & 52.746 & 458 & & & & & & \\
\hline & \multirow{3}{*}{ PPR } & Between groups & 25.946 & 155 & \multirow{3}{*}{155} & \multirow{3}{*}{303} & 0.167 & \multirow{3}{*}{1.738} & \multirow{3}{*}{0.000} & \multirow{3}{*}{$\begin{array}{l}\text { PPR has an } \\
\text { effect on MET }\end{array}$} \\
\hline & & Within groups & 29.188 & 303 & & & \multirow{2}{*}{0.096} & & & \\
\hline & & Total & 55.134 & 458 & & & & & & \\
\hline & \multirow{3}{*}{ FMS } & Between groups & 25.500 & 155 & \multirow{3}{*}{155} & \multirow{3}{*}{303} & 0.165 & \multirow{3}{*}{1.774} & \multirow{3}{*}{0.000} & \multirow{3}{*}{$\begin{array}{l}\text { FMS has an } \\
\text { effect on MET }\end{array}$} \\
\hline & & Within groups & 28.107 & 303 & & & \multirow{2}{*}{0.093} & & & \\
\hline & & Total & 53.607 & 458 & & & & & & \\
\hline & \multirow{3}{*}{$\mathrm{CNC}$} & Between groups & 24.156 & 155 & \multirow{3}{*}{155} & \multirow{3}{*}{303} & 0.156 & \multirow{3}{*}{1.945} & & \\
\hline & & Within groups & 24.279 & 303 & & & & & 0.000 & $\begin{array}{l}\text { CNC has an } \\
\text { effect on MET }\end{array}$ \\
\hline & & Total & 48.435 & 458 & & & 0.080 & & & \\
\hline & & Between groups & 30.639 & 155 & & & 4.801 & & & \\
\hline & PLC & Within groups & 27.174 & 303 & 155 & 303 & & 2.204 & 0.000 & $\begin{array}{l}\text { PLC has an } \\
\text { effect on MET }\end{array}$ \\
\hline & & Total & 57.813 & 458 & & & 0.000 & & & \\
\hline & & Between groups & 30.141 & 155 & & & 0.194 & & & \\
\hline & CIM & Within groups & 26.075 & 303 & 155 & 303 & 0086 & 2.260 & 0.000 & $\begin{array}{l}\text { CIM has an } \\
\text { effect on MET }\end{array}$ \\
\hline & & Total & 56.215 & 458 & & & & & & \\
\hline & & Between groups & 30.796 & 142 & & & 0.217 & & & \\
\hline & RWM & Within groups & 24.046 & 316 & 142 & 316 & & 2.850 & 0.000 & $\begin{array}{l}\text { RWM has an } \\
\text { effect on PTK. }\end{array}$ \\
\hline & & Total & 54.842 & 458 & & & 0.076 & & & \\
\hline & & Between groups & 27.640 & 142 & & & 0.195 & & & \\
\hline & RCS & Within groups & 24.490 & 316 & 142 & 316 & & 2.512 & 0.000 & $\begin{array}{c}\text { RCS has an } \\
\text { effect on PTK. }\end{array}$ \\
\hline & & Total & 52.130 & 458 & & & & & & \\
\hline PTK & & Between groups & 28.902 & 142 & & & 0.205 & & & \\
\hline & RSC & Within groups & 23.400 & 316 & 142 & 316 & & 2.768 & 0.000 & $\begin{array}{l}\text { RSC has an } \\
\text { effect on PTK }\end{array}$ \\
\hline & & Total & 52.302 & 457 & & & 0.074 & & & \\
\hline & & Between groups & 25.482 & 142 & & & 0.179 & & & \\
\hline & SOP & Within groups & 24.349 & 316 & 142 & 316 & & 2.329 & 0.000 & $\begin{array}{l}\text { SOP has an } \\
\text { effect on PTK. }\end{array}$ \\
\hline & & Total & 49.831 & 458 & & & 0.077 & & & \\
\hline & & Between groups & 28.788 & 142 & & & 0.203 & & & \\
\hline & E-M & Within groups & 22.766 & 316 & 142 & 316 & 0.072 & 2.814 & 0.000 & $\begin{array}{l}\text { E-M has an } \\
\text { effect on PTK. }\end{array}$ \\
\hline & & Total & 51.554 & 458 & & & & & & \\
\hline
\end{tabular}


Table 10: Continued.

\begin{tabular}{|c|c|c|c|c|c|c|c|c|c|c|}
\hline Area & Factor & Sum of squa & res & DF & $v_{1}$ & $v_{2}$ & $\begin{array}{l}\text { Mean } \\
\text { square }\end{array}$ & $f_{0}$ & $P$ value & Conclusion \\
\hline \multirow{12}{*}{ QPIM } & \multirow{3}{*}{ FID } & Between groups & 27.024 & 123 & \multirow{3}{*}{123} & \multirow{3}{*}{335} & 0.220 & \multirow{3}{*}{2.914} & \multirow{3}{*}{0.000} & \multirow{3}{*}{$\begin{array}{l}\text { FID has an } \\
\text { effect on } \\
\text { QPIM. }\end{array}$} \\
\hline & & Within groups & 25.256 & 335 & & & \multirow{2}{*}{0.075} & & & \\
\hline & & Total & 52.280 & 458 & & & & & & \\
\hline & \multirow{3}{*}{ LPP } & Between groups & 25.765 & 123 & \multirow{3}{*}{123} & \multirow{3}{*}{335} & 0.209 & \multirow{3}{*}{3.064} & \multirow{3}{*}{0.000} & \multirow{3}{*}{$\begin{array}{l}\text { LPP has an } \\
\text { effect on } \\
\text { QPIM. }\end{array}$} \\
\hline & & Within groups & 22.905 & 335 & & & & & & \\
\hline & & Total & 48.670 & 458 & & & 0.068 & & & \\
\hline & \multirow{3}{*}{ MBF } & Between groups & 27.214 & 123 & \multirow{3}{*}{123} & \multirow{3}{*}{335} & 0.221 & & \multirow{3}{*}{0.000} & \multirow{3}{*}{$\begin{array}{c}\text { MBF has an } \\
\text { effect on } \\
\text { QPIM. }\end{array}$} \\
\hline & & Within Groups & 25.076 & 335 & & & \multirow{2}{*}{0.075} & \multirow[t]{2}{*}{2.956} & & \\
\hline & & Total & 52.290 & 458 & & & & & & \\
\hline & \multirow{3}{*}{ FPT } & Between groups & 30.022 & 123 & \multirow{3}{*}{123} & \multirow{3}{*}{335} & 0.244 & & \multirow{3}{*}{0.000} & \multirow{3}{*}{$\begin{array}{l}\text { FPT has an } \\
\text { effect on } \\
\text { QPIM. }\end{array}$} \\
\hline & & Within groups & 31.739 & 335 & & & & \multirow[t]{2}{*}{2.576} & & \\
\hline & & Total & 61.761 & 458 & & & & & & \\
\hline & & Between groups & 14.408 & 63 & & & 0.229 & & & \\
\hline & EIS & Within groups & 42.077 & 395 & 63 & 395 & & 2.147 & 0.000 & $\begin{array}{c}\text { EIS has an } \\
\text { effect on PPC. }\end{array}$ \\
\hline & & Total & 56.484 & 458 & & & 10.10 & & & \\
\hline & & Between groups & 27.184 & 63 & & & 0.431 & & & \\
\hline & MTO & Within groups & 33.016 & 395 & 63 & 395 & 0.084 & 5.162 & 0.000 & $\begin{array}{l}\text { MTO has an } \\
\text { effect on PPC. }\end{array}$ \\
\hline & & Total & 60.200 & 458 & & & & & & \\
\hline & & Between groups & 25.489 & 63 & & & 0.405 & & & \\
\hline & DMK & Within groups & 34.816 & 395 & 63 & 395 & & 4.590 & 0.000 & $\begin{array}{l}\text { DMK has an } \\
\text { effect on PPC. }\end{array}$ \\
\hline & & Total & 60.305 & 458 & & & 0.088 & & & \\
\hline & & Between groups & 22.479 & 63 & & & 0.357 & & & \\
\hline & MRP & Within groups & 32.326 & 395 & 63 & 395 & $108 ?$ & 4.360 & 0.000 & $\begin{array}{l}\text { MRP has an } \\
\text { effect on PPC. }\end{array}$ \\
\hline & & Total & 54.805 & 458 & & & & & & \\
\hline & & Between groups & 28.842 & 157 & & & 0.184 & & & \\
\hline & HFS & Within groups & 20.503 & 301 & 157 & 301 & & 2.697 & 0.000 & $\begin{array}{l}\text { HFS has an } \\
\text { effect on SFM. }\end{array}$ \\
\hline & & Total & 49.345 & 458 & & & 8 & & & \\
\hline & & Between groups & 25.126 & 157 & & & 0.160 & & & \\
\hline & GPE & Within groups & 21.336 & 301 & 157 & 301 & & 2.258 & 0.000 & $\begin{array}{l}\text { GPE has an } \\
\text { effect on SFM. }\end{array}$ \\
\hline & & Total & 46.462 & 458 & & & & & & \\
\hline SFM & & Between groups & 30.429 & 157 & & & 0.194 & & & \\
\hline & ECT & Within groups & 26.146 & 301 & 157 & 301 & 007 & 2.231 & 0.000 & $\begin{array}{l}\text { ECT has an } \\
\text { effect on SFM. }\end{array}$ \\
\hline & & Total & 56.575 & 458 & & & & & & \\
\hline
\end{tabular}


Table 10: Continued.

\begin{tabular}{|c|c|c|c|c|c|c|c|c|c|c|}
\hline \multirow[t]{7}{*}{ Area } & \multirow{4}{*}{$\begin{array}{l}\text { Factor } \\
\text { RWM }\end{array}$} & \multicolumn{2}{|c|}{ Sum of squares } & \multirow{2}{*}{$\begin{array}{c}\text { DF } \\
157\end{array}$} & \multirow[t]{2}{*}{$v_{1}$} & \multirow[t]{2}{*}{$v_{2}$} & \multirow{2}{*}{$\begin{array}{c}\begin{array}{c}\text { Mean } \\
\text { square }\end{array} \\
0.204\end{array}$} & \multirow[t]{2}{*}{$f_{0}$} & \multirow[t]{2}{*}{$P$ value } & \multirow[t]{2}{*}{ Conclusion } \\
\hline & & Between groups & 32.023 & & & & & & & \\
\hline & & Within Groups & 22.819 & 301 & 157 & 301 & & 2.690 & 0.000 & $\begin{array}{l}\text { RWM has an } \\
\text { effect on SFM. }\end{array}$ \\
\hline & & Total & 54.842 & 458 & & & 0.076 & & & \\
\hline & \multirow{6}{*}{ QIN } & Between groups & 28.198 & 157 & \multirow{3}{*}{157} & \multirow{3}{*}{301} & 0.180 & \multirow{3}{*}{2.625} & \multirow{3}{*}{0.000} & \multirow{3}{*}{$\begin{array}{l}\text { MLT has an } \\
\text { effect on SFM. }\end{array}$} \\
\hline & & Within groups & 20.592 & 301 & & & \multirow{2}{*}{0.068} & & & \\
\hline & & Total & 48.790 & 458 & & & & & & \\
\hline \multirow{12}{*}{ PDD } & & Between groups & 32.806 & 198 & & & 0.166 & \multirow{3}{*}{1.899} & \multirow{3}{*}{0.000} & \multirow{3}{*}{$\begin{array}{l}\text { QIN has an } \\
\text { effect on PDD. }\end{array}$} \\
\hline & & Within groups & 22.685 & 260 & 198 & 260 & \multirow{2}{*}{0.087} & & & \\
\hline & & Total & 55.491 & 458 & & & & & & \\
\hline & \multirow{3}{*}{ RCC } & Between groups & 34.958 & 198 & \multirow{3}{*}{198} & \multirow{3}{*}{260} & 0.177 & \multirow{3}{*}{2.078} & \multirow{3}{*}{0.000} & \\
\hline & & Within groups & 22.088 & 260 & & & & & & $\begin{array}{l}\text { RCC has an } \\
\text { effect on PDD. }\end{array}$ \\
\hline & & Total & 57.046 & 458 & & & & & & \\
\hline & & Between groups & 31.232 & 198 & & & 0.158 & & & \\
\hline & E-M & Within groups & 20.322 & 260 & 198 & 260 & & 2.018 & 0.000 & $\begin{array}{l}\text { E-M has an } \\
\text { effect on PDD. }\end{array}$ \\
\hline & & Total & 51.554 & 458 & & & . & & & \\
\hline & & Between groups & 35.112 & 198 & & & 0.177 & & & \\
\hline & CIM & Within groups & 21.103 & 260 & 198 & 260 & 0081 & 2.185 & 0.000 & $\begin{array}{l}\text { CIM has an } \\
\text { effect on PDD. }\end{array}$ \\
\hline & & Total & 56.215 & 458 & & & & & & \\
\hline & & Between groups & 32.171 & 57 & & & 0.564 & & & \\
\hline & ECT & Within groups & 24.404 & 401 & 57 & 401 & & 9.274 & 0.000 & $\begin{array}{c}\text { ECT has an } \\
\text { effect on SRM. }\end{array}$ \\
\hline & & Total & 56.575 & 458 & & & .001 & & & \\
\hline & & Between groups & 25.975 & 57 & & & 0.456 & & & \\
\hline SRM & LTR & Within groups & 24.947 & 401 & 57 & 401 & & 7.325 & 0.000 & $\begin{array}{l}\text { LTR has an } \\
\text { effect on SRM. }\end{array}$ \\
\hline & & Total & 50.922 & 458 & & & 0.062 & & & \\
\hline & & Between groups & 27.583 & 57 & & & 0.484 & & & \\
\hline & SES & Within groups & 25.817 & 401 & 57 & 401 & 0.064 & 7.516 & 0.000 & $\begin{array}{l}\text { SES has an } \\
\text { effect on SRM. }\end{array}$ \\
\hline & & Total & 53.400 & 458 & & & & & & \\
\hline & & Between groups & 23.490 & 67 & & & 0.351 & & & \\
\hline & IQD & Within groups & 32.175 & 391 & 67 & 391 & & 4.260 & 0.000 & $\begin{array}{l}\text { IQD has an } \\
\text { effect on CRM }\end{array}$ \\
\hline & & Total & 55.665 & 458 & & & .0082 & & & \\
\hline & & Between groups & 19.922 & 67 & & & 0.297 & & & \\
\hline & ECT & Within groups & 36.653 & 391 & 67 & 391 & & 3.172 & 0.000 & $\begin{array}{l}\text { ECT has an } \\
\text { effect on CRM }\end{array}$ \\
\hline & & Total & 56.575 & 458 & & & & & & \\
\hline
\end{tabular}


Table 10: Continued.

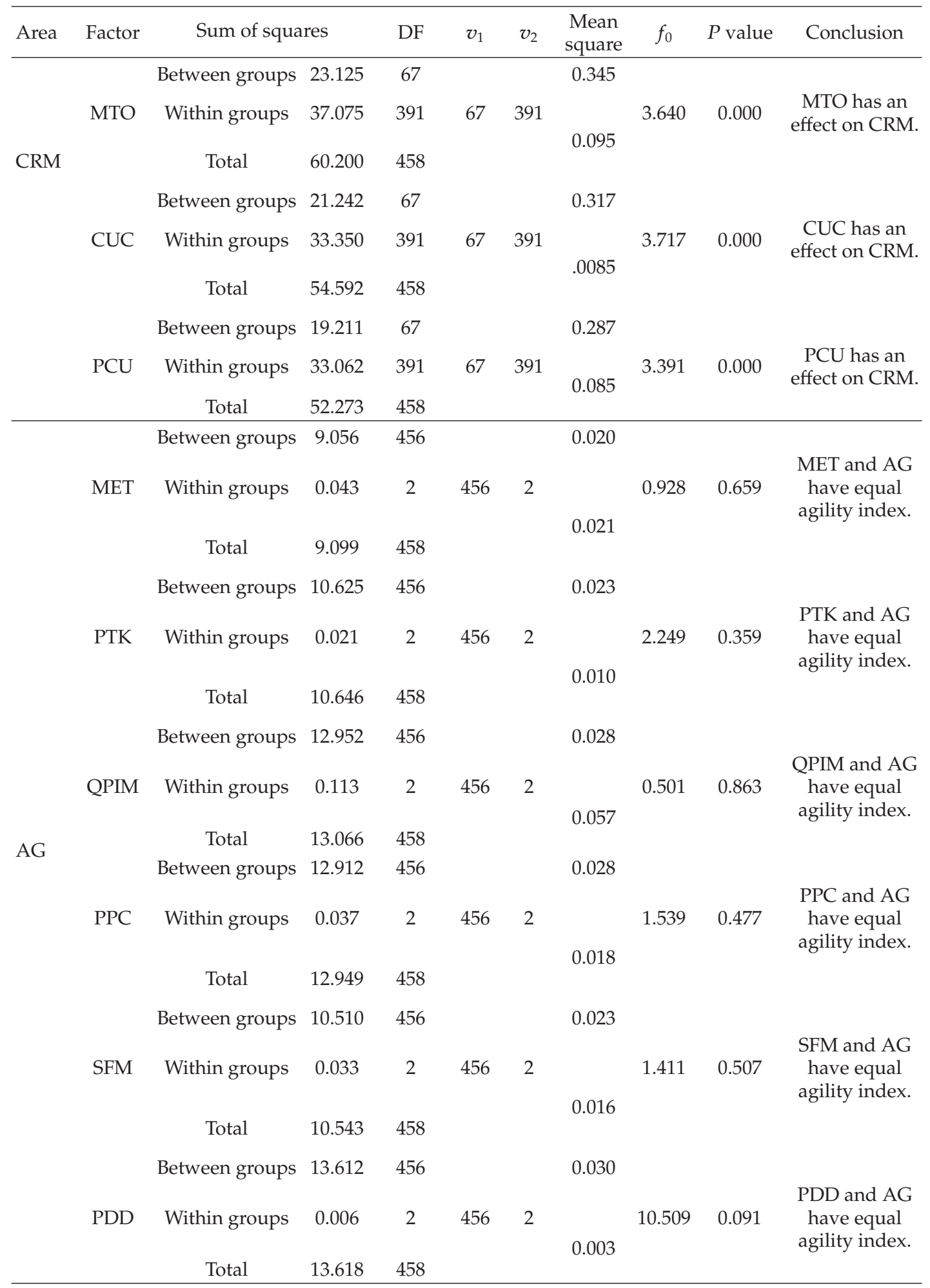


Table 10: Continued.

\begin{tabular}{|c|c|c|c|c|c|c|c|c|c|c|}
\hline \multirow[t]{2}{*}{ Area } & \multirow[t]{2}{*}{ Factor } & \multicolumn{2}{|c|}{ Sum of squares } & \multirow{2}{*}{$\begin{array}{l}\mathrm{DF} \\
456\end{array}$} & \multirow[t]{2}{*}{$v_{1}$} & \multirow[t]{2}{*}{$v_{2}$} & \multirow{2}{*}{$\begin{array}{c}\begin{array}{c}\text { Mean } \\
\text { square }\end{array} \\
0.040\end{array}$} & \multirow[t]{2}{*}{$f_{0}$} & \multirow[t]{2}{*}{$P$ value } & \multirow[t]{2}{*}{ Conclusion } \\
\hline & & Between groups & 18.103 & & & & & & & \\
\hline & \multirow[t]{2}{*}{ SRM } & Within groups & 0.036 & 2 & \multirow[t]{2}{*}{456} & \multirow[t]{2}{*}{2} & & \multirow[t]{2}{*}{2.233} & \multirow[t]{2}{*}{0.361} & \multirow[t]{2}{*}{$\begin{array}{l}\text { SRM and AG } \\
\text { have equal } \\
\text { agility index. }\end{array}$} \\
\hline & & Total & 18.139 & 458 & & & 0.018 & & & \\
\hline & \multirow{3}{*}{ CRM } & Between groups & 10.186 & 456 & \multirow{3}{*}{456} & \multirow{3}{*}{2} & 0.022 & & \multirow{3}{*}{0.033} & \multirow{3}{*}{$\begin{array}{l}\text { CRM and AG } \\
\text { have equal } \\
\text { agility index. }\end{array}$} \\
\hline & & Within groups & 0.002 & 2 & & & \multirow{2}{*}{0.001} & 29.566 & & \\
\hline & & Total & 10.188 & 458 & & & & & & \\
\hline
\end{tabular}

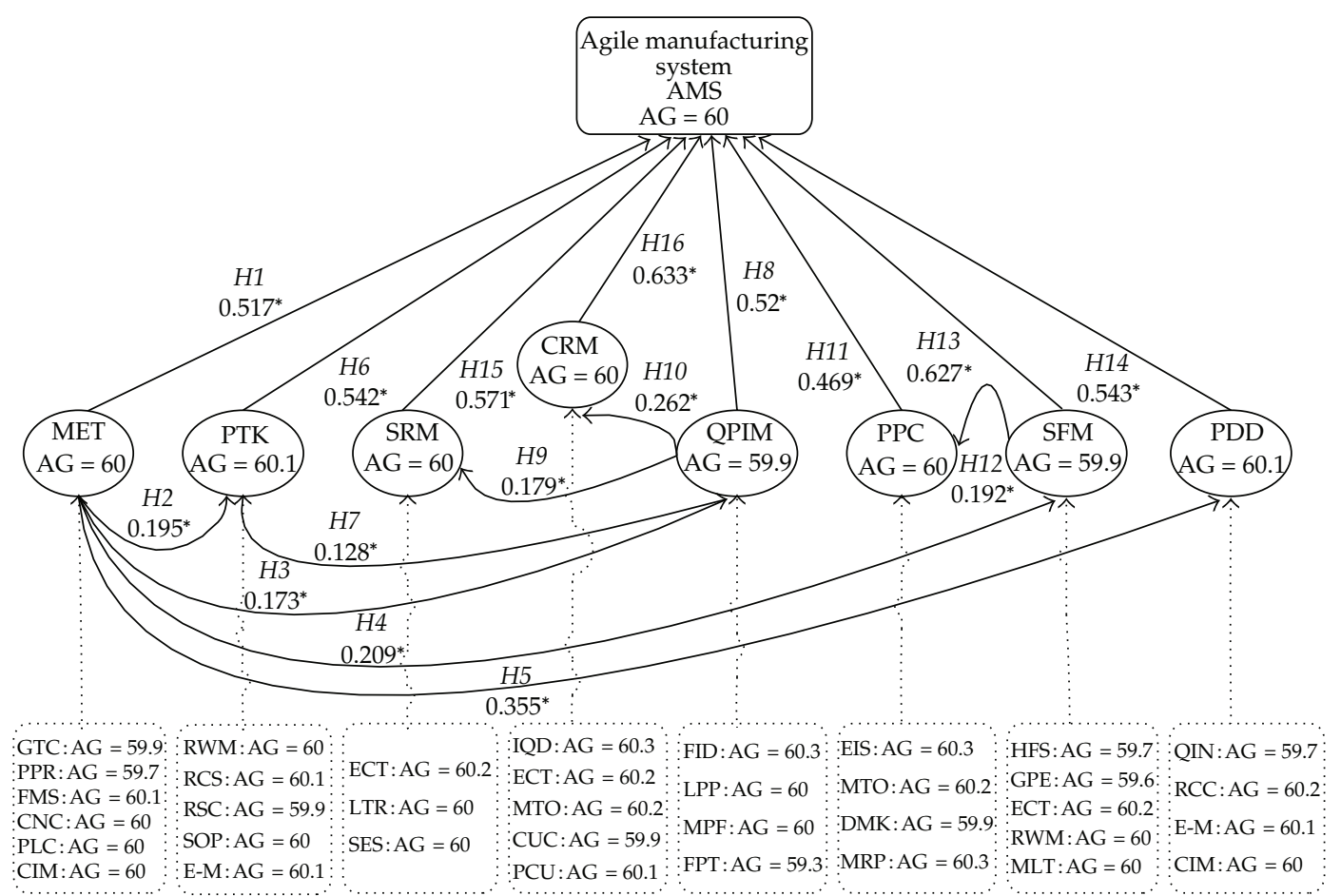

Figure 2: Estimates of the relations between models constructs.

their AMS systems are identified based on empirical basis. This paper concludes that the existence of 36 different agile approaches can be adopted by the different firms to enhance their competitiveness. These approaches categorized into eight impact areas, namely, MET, PTK, QPIM, PPC, SFM, PDD, SRM, and CRM. The primary contribution of this paper is successfully analyzing the causal relationship of implementation level of agile production areas and their effect on the AMS using SME methodology. The results ensure that SEM is the correct method for investigating the relationship model between the eight-constructs considered in this study. IBM SPSS 20 and AMOS 19.0.0 software enable SEM to provide a 
clear and complete specification of the AMS and its constructs. The results of this study show that the studied agile tactics have significant relationship and are affected positively by the AMS. The implementation of each agile tactic contributes significantly to the performance of AMS. The approach presented in this study can be used to facilitate the implementation of agile practices in industries and measure correlation between them. It may be worthwhile to focus future research on modeling the implementation of lean production practices, such as kanban, just in time (JIT), pull production control strategy, and so forth, [60] and to compare and link the expected results with those concluded here.

\section{Acknowledgments}

The authors are thankful to the anonymous referees for their valuable comments and suggestions which improved the presentation of the paper.

\section{References}

[1] M. P. Groover, Automation, Production Systems, \& Computer Integrated Manufacturing, Prentice Hall, 2nd edition, 2001.

[2] D. T. Pham, Z. Ebrahim, T. Shamsuddin, R. Barton, and O. Williams, "The relationship between lean manufacturing agile manufacturing \& sustainability," in Innovative PRoduction Machines \& Systems (I'PROMS '08), Cardiff University, July 2008.

[3] CAM-I, Description, modeling \& simulation of next generation manufacturing systems, a proposal to the European Commission for an International Intelligent Manufacturing Systems Project No. 95002, 1998.

[4] J. Prince and J. M. Kay, "Combining lean \& agile characteristics: creation of virtual groups by enhanced production flow analysis," International Journal of Production Economics, vol. 85, no. 3, pp. 305-318, 2003.

[5] A. Shahin and N. Janatyan, "Group technology (GT) \& lean production: a conceptual model for enhancing productivity," International Business Research, vol. 3, no. 4, 2010.

[6] J. Norin and D. Karlström, Lean configuration management, softhouse consulting, Stormgatan 14 SE-211 20, Malmö, Sweden, 2006.

[7] C. Tsai and C. Lee, "Optimization of manufacturing cell formation with a multi-functional mathematical programming model," International Journal of Advanced Manufacturing Technology, vol. 30, no. 3-4, pp. 309-318, 2006.

[8] W. Hachicha, F. Masmoudi, and M. Haddar, "Formation of machine groups \& part families in cellular manufacturing systems using a correlation analysis approach," International Journal of Advanced Manufacturing Technology, vol. 36, no. 11-12, pp. 1157-1169, 2008.

[9] R. Li-Hua and T. Khalil, "Technology management in China: a global perspective \& challenging issues," Journal of Technology Management in China, vol. 1, no. 1, pp. 9-26, 2006.

[10] H. Vehkapera, H. Haapasalo, and J. Rusanen, "Analysis of technology management functions in finish high tech companies," The Open Management Journal, vol. 2, pp. 1-10, 2009.

[11] A. Lee, W. Wang, and T. Lin, "An evaluation framework for technology transfer of new equipment in high technology industry," Technological Forecasting \& Social Change, vol. 77, no. 1, pp. 135-150, 2010.

[12] K. Piirainen, K. Elfvengren, J. Korpela, and M. Tuominen, "Improving the effectiveness of business process development through collaboration engineering: a method for process elicitation," in Proceedings of the 42nd Annual Hawaii International Conference on System Sciences (HICSS '09), January 2009.

[13] P. Chutima and K. Kaewin, "Using lean \& business process reengineering (BPR) model for improving agility," in Proceedings of the IE Network Conference, 2007.

[14] Y. Yusuf, M. Sarhadi, and A. Gunasekaran, "Agile manufacturing: the drivers, concepts \& attributes," International Journal of Production Economics, vol. 62, no. 1, pp. 33-43, 1999.

[15] D. B. Ganesh and D. T. Marvin, "Examining the relationship between business process improvement initiatives, information systems integration \& customer focus: an empirical study," Business Process Management Journal, vol. 11, no. 5, pp. 532-558, 2005. 
[16] S. Vinodh, G. Sundararaj, and S. R. Devadasan, "Measuring organisational agility before \& after implementation of TADS," International Journal of Advanced Manufacturing Technology, vol. 47, no. 5-8, pp. 809-818, 2010.

[17] R. D. Quinn, G. C. Causey, F. L. Merat et al., "An agile manufacturing workcell design," IIE Transactions, vol. 29, no. 10, pp. 901-909, 1997.

[18] L. R. Francisco and T. Manuela, "Exploring agile methods in construction small \& medium enterprises: a case study," Journal of Enterprise Information Management, vol. 23, no. 2, pp. 161-180, 2010.

[19] A. Gunasekaran, "Agile manufacturing: enablers \& an implementation framework," International Journal of Production Research, vol. 36, no. 5, pp. 1223-1247, 1998.

[20] A. M. Hormozi, “Agile manufacturing: the next logical step," Benchmarking, vol. 8, no. 2, pp. 132-143, 2001.

[21] S. C. Misra, V. Kumar, and U. Kumar, "Identifying some critical changes required in adopting agile practices in traditional software development projects," International Journal of Quality $\mathcal{E}$ Reliability Management, vol. 27, no. 4, pp. 451-474, 2010.

[22] A. C. S\&erson, R. J. Graves, and D. L. Millard, "Multipath agility in electronics manufacturing," in Proceedings of IEEE International Conference on Systems, Man \& Cybernetics, vol. 1, pp. 501-505, October 1994.

[23] M. F. Assen, E. W. Hans, and S. L. Velde, “An agile planning \& control framework for customer-order driven discrete parts manufacturing environments," International Journal of Agile Management Systems, vol. 2, no. 1, pp. 16-23, 2000.

[24] J. P. MacDuffie, "Human resource bundles \& manufacturing performance: organizational logic \& flexible production systems in the world auto industry," Industrial \& Labor Relations Review, vol. 48, no. 2, pp. 197-221, 1995.

[25] R. G. Schroeder, K. A. Bates, and M. A. Junttila, "A resource-based view of manufacturing strategy \& the relationship to manufacturing performance," Strategic Management Journal, vol. 23, no. 2, pp. 105-117, 2002.

[26] A. Gunasekaran, "Agile manufacturing: a framework for research \& development," International Journal of Production Economics, vol. 62, no. 1, pp. 87-105, 1999.

[27] R. Dove, "Measuring agility: the toll of turmoil," Production, vol. 107, no. 1, pp. 12-14, 1995.

[28] B. Naylor, M. M. Naim, and D. Berry, "Leagility: integrating the lean \& agile manufacturing paradigms in the total supply chain," International Journal of Production Economics, vol. 62, no. 1, pp. 107-118, 1999.

[29] D. B. Sieger, A. Badiru, and M. Milatovic, "A metric for agility measurement in product development," IIE Transactions, vol. 32, no. 7, pp. 637-645, 2000.

[30] S. Vinodh and D. Kuttalingam, "Computer-aided design \& engineering as enablers of agile manufacturing: a case study in an Indian manufacturing organization," Journal of Manufacturing Technology Management, vol. 22, no. 3, pp. 405-418, 2011.

[31] H. S. Yan, An Approach to Workshop Stochastic Production Planning in Agile Manufacturing Environment, Southeast University, Jiangsu, China, 1998.

[32] C. W. Li, K. L. Sian, and P. H. Li, "A RFID based agile manufacturing planning \& control system," International Journal of Production Economics, vol. 75, pp. 1-2, 2002.

[33] Z. X. Chen, "Problems of production management in agile manufacturing environment \& their counter measures," Journal of Xiamen University (Natural Science), no. S1, 2002.

[34] V. T. Le, B. M. Gunn, and S. Nahavandi, "MRP—production planning in agile manufacturing," in Proceedings of the 2nd International IEEE Conference "Intelligent Systems", Varna, Bulgaria, June 2004.

[35] T. Tunglun and R. Sato, "A UML model of agile production planning \& control system," Computers in Industry, vol. 53, no. 2, pp. 133-152, 2004.

[36] B. Golds and J. Thomas, "Modeling Lean, agile, and leagile supply chain strategies," Journal of Business Logistics, vol. 27, no. 1, pp. 57-80, 2006.

[37] T. Ching, Y. Lin, C. C. Te, and Y. Cheng, "Agile manufacturing and information system design-a Taiwan case," in Proceedings of IEEE International Conference on Systems, Man and Cybernetics, October 2004.

[38] E. Adrian M. Coronado, S. Mansoor, and M. Colin, “Defining a framework for information systems requirements for agile manufacturing," International Journal of Production Economics, vol. 75, no. 1, pp. 57-68, 2002.

[39] K. Lenny and S. Mike, Change E Uncertainty in SME Manufacturing Environments Using ERP, Emerald Group, 2005. 
[40] T. Petri, "Agile production management: an analysis of capacity decisions \& order-fulfillment time," International Journal of Agile Systems \& Management, vol. 1, no. 1, pp. 2-10, 2006-.

[41] B. David and W. Chong, "A literature review of decision-making models \& approaches for partner selection in agile supply chains," Journal of Purchasing E Supply Management, vol. 17, no. 4, pp. 256$274,2011$.

[42] G. Langer and L. Alting, "An architecture for agile shop floor control systems," Journal of Manufacturing Systems, vol. 19, no. 4, pp. 267-281, 2000.

[43] C. Bang, Hybrid integration-approach for process planning $\mathcal{E}$ shop floor scheduling in agile manufacturing [Ph.D. thesis], State University of New York, Buffalo, NY, USA, 2002.

[44] L. Ribeiro, J. Barata, and A. Colombo, "Supporting agile supply chains using a service-oriented shop floor," Engineering Applications of Artificial Intelligence, vol. 22, no. 6, pp. 950-960, 2009.

[45] Y. Li, J. Q. Zheng, and S. L. Yang, "Multi-agent-based fuzzy scheduling for shop floor," International Journal of Advanced Manufacturing Technology, vol. 49, no. 5-8, pp. 689-695, 2010.

[46] Y. Kim, J. Y. Jo, V. B. Velasco et al., "Flexible software architecture for agile manufacturing," in Proceedings of IEEE International Conference on Robotics E Automation, (ICRA '97), vol. 4, pp. 3043-3047, April 1997.

[47] M. Jacobs, C. Droge, S. K. Vickery, and R. Calantone, "Product \& process modularity's effects on manufacturing agility \& firm growth performance," Journal of Product Innovation Management, vol. 28, no. 1, pp. 123-137, 2011.

[48] S. E. Chick, T. L. Olsen, K. Sethuraman, K. E. Stecke, and C. C. White III, “A descriptive multi-attribute model for reconfigurable machining system selection examining buyer-supplier relationships," International Journal of Agile Management Systems, vol. 2, no. 1, pp. 33-48, 2000.

[49] P. M. Swafford, S. Ghosh, and N. Murthy, "Achieving supply chain agility through IT integration \& flexibility," International Journal of Production Economics, vol. 116, no. 2, pp. 288-297, 2008.

[50] C. Forsythe, "Human factors in agile manufacturing: a brief overview with emphasis on communications \& information infrastructure," Human Factors \& Ergonomics in Manufacturing, vol. 7, no. 1, pp. 3-10, 1997.

[51] L. Chunxia and Z. Shensheng, "Reconfiguration based agile supply chain system," in Proceedings of IEEE International Conference on Systems, Man \& Cybernetics, Tucson, Ariz, USA, October 2001.

[52] P. R. Moore, J. Pu, H. C. Ng et al., "Virtual engineering: an integrated approach to agile manufacturing machinery design \& control," Mechatronics, vol. 13, no. 10, pp. 1105-1121, 2003.

[53] L. M. Andrew, "Improved product design as an alternative to outsourcing manufacture \& assembly," Assembly Automation, vol. 26, no. 2, pp. 121-126, 2006.

[54] S. Vinodh, S. R. Devadasan, and C. Shankar, “Design agility through computer aided design," Journal of Engineering, Design \& Technology, vol. 8, no. 1, pp. 94-106, 2010.

[55] Y. Y. Yusuf and E. O. Adeleye, "A comparative study of lean \& agile manufacturing with a related survey of current practices in the UK," International Journal of Production Research, vol. 40, no. 17, pp. 4545-4562, 2002.

[56] A. H. M. Shamsuzzoha, "Modular product architecture for productivity enhancement," Business Process Management Journal, vol. 17, no. 1, pp. 21-41, 2011.

[57] H. S. Yan and J. Jiang, "Agile concurrent engineering," Integrated Manufacturing Systems, vol. 10, no. 2, pp. 103-113, 1999.

[58] A. Gunasekaran and Y. Y. Yusuf, "Agile manufacturing: a taxonomy of strategic \& technological imperatives," International Journal of Production Research, vol. 40, no. 6, pp. 1357-1385, 2002.

[59] S. Paul, "With agility \& adequate partnership strategies towards effective logistics networks," Computers in Industry, vol. 42, no. 1, pp. 33-42, 2000.

[60] M. D. Al-Tahat, D. Dalalah, and M. A. Barghash, "Dynamic programming model for multi-stage single-product Kanban-controlled serial production line," Journal of Intelligent Manufacturing, vol. 23, no. 1, pp. 37-48, 2009. 


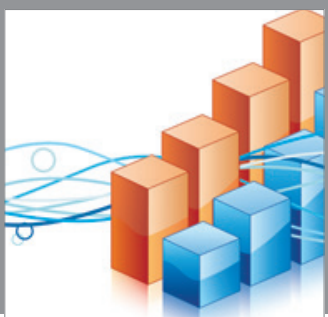

Advances in

Operations Research

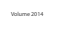

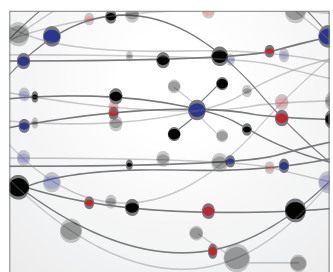

\section{The Scientific} World Journal
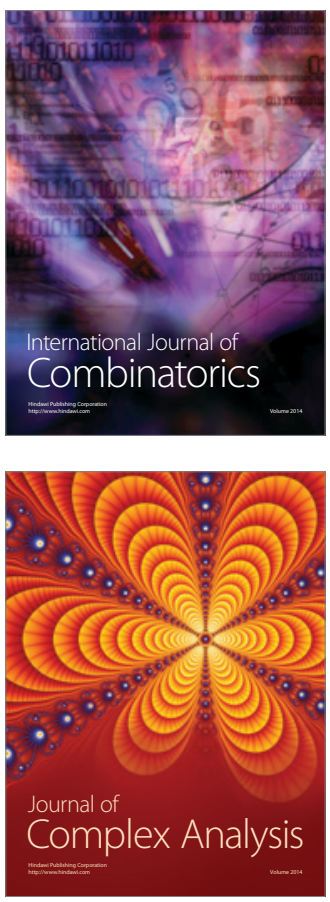

International Journal of

Mathematics and

Mathematical

Sciences
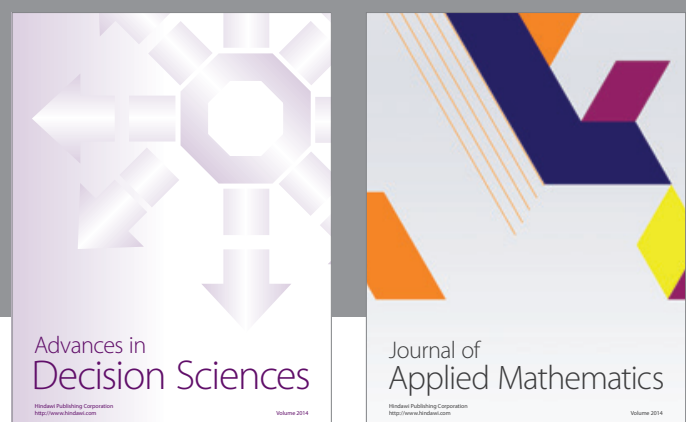

Journal of

Applied Mathematics
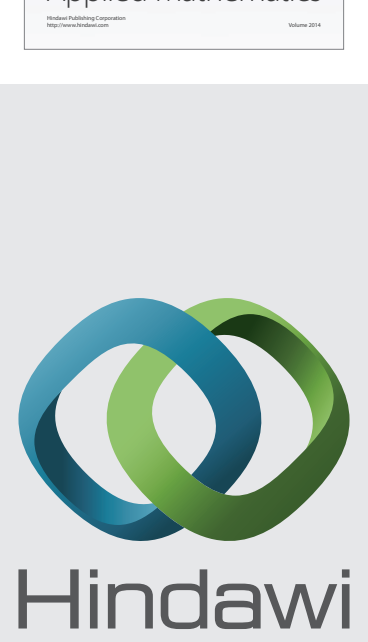

Submit your manuscripts at http://www.hindawi.com
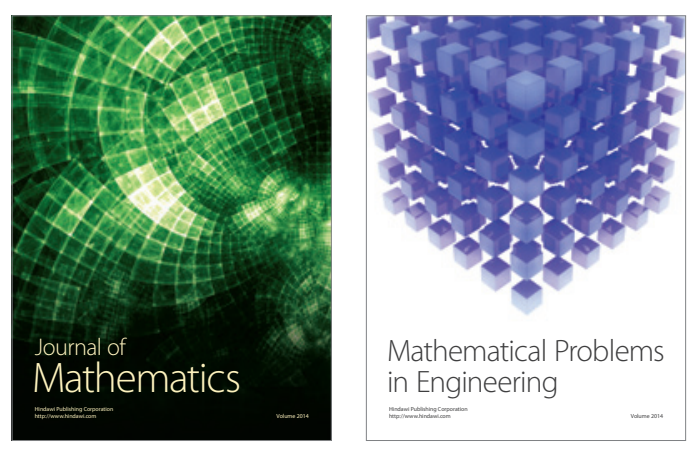

Mathematical Problems in Engineering
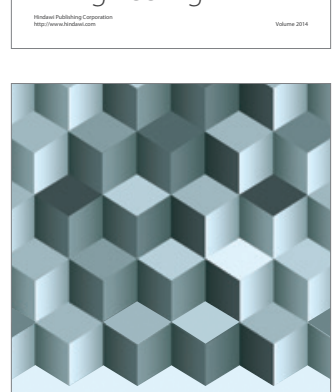

Journal of

Function Spaces
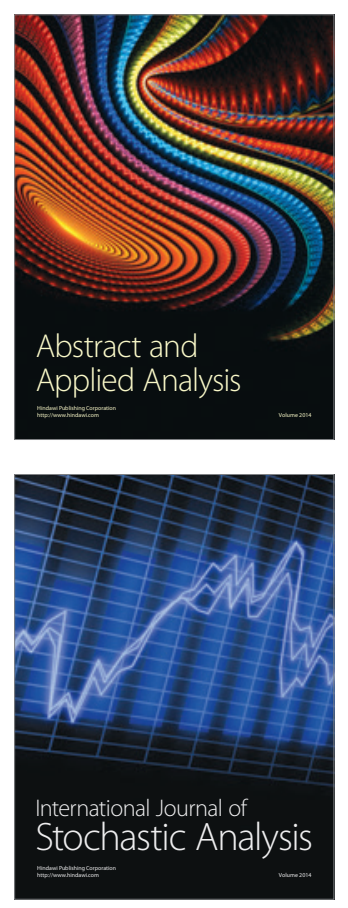

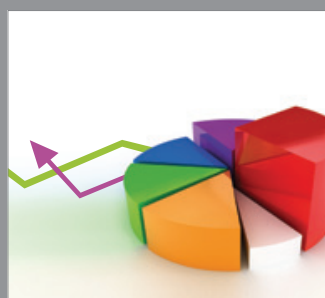

ournal of

Probability and Statistics

Promensencen
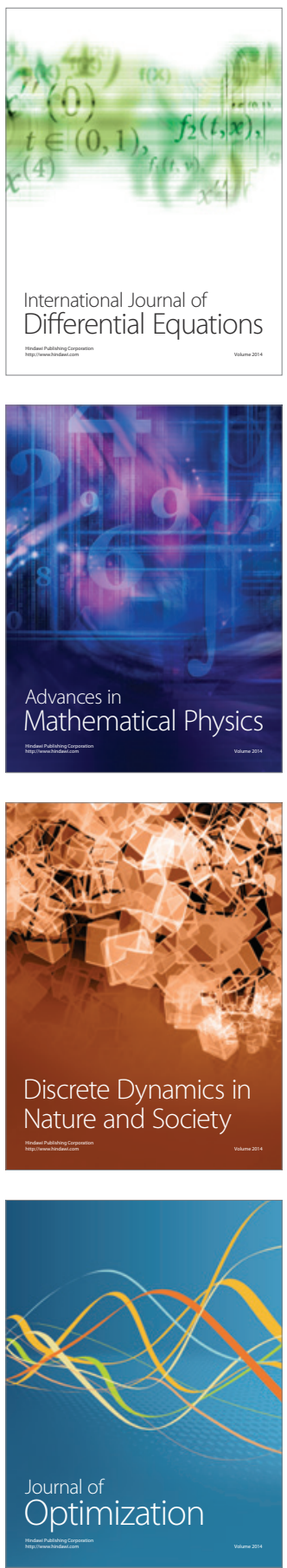